\title{
A tőkeáttételi ráta bevezetésének várható hatá- sai hazai és EU-szinten*
}

\author{
Kocsis Beáta - Seregdi László
}

2021 júniusától az Európai Unióban az ott bejegyzett valamennyi hitelintézetre új, kötelezö követelményrendszer lép hatályba, amely részletesen meghatározza a tőkeáttételi mutató számítási módját és minimumának szintjét. E tanulmányban összefoglaljuk a tőkeáttételi ráta szabályozásának főbb ismérveit, bevezetésének indokait, valamint a rájuk vonatkozó kritikákat. Megvizsgáljuk az új követelmények várható hatásait és azt is, hogy mely hitelintézeti típusokat érintheti a leginkább érzékenyen, valamint hogy a tőkeáttételi ráta hogyan kapcsolódik a prudenciális szabályozás egyes, már eddig is alkalmazott elemeihez. Elméleti és gyakorlati példán keresztül keressük a választ arra, hogy a tökeáttételi ráta mikor válhat effektiv korláttá a tőkemegfelelési követelményekkel szemben, és milyen intézményi sajátosságok esetén lehet ideális kiegészítőjük. A tanulmány készítéséhez felhasználtuk a tőkeáttételi rátával foglalkozó nemzetközi szakirodalmat, az Európai Bankhatóság elemzéseit, valamint a felügyeleti adatszolgáltatásból elérhető információkat. Következtetésünk szerint a tökeáttételi ráta a jelenlegi formájában a hazai hitelintézetek többségére nem gyakorol jelentős hatást, és nemzetközi viszonylatban is elsősorban csak azon hitelintézetek esetében jelent majd tényleges korlátot, amelyek sajátos üzleti modellel, alacsony átlagos kockázati súlyok mellett müködnek.

Journal of Economic Literature (JEL) kódok: E44, E58, G21

Kulcsszavak: tőkeáttételi ráta, bankrendszer, prudenciális szabályozás

\section{Bevezetés}

A tőkeáttételi ráta mint minimumkövetelmény bevezetésének a gondolata a 2008-as globális pénzügyi válságot követően merült fel. Ugyan hasonló jellegű szabályozás már korábban is létezett, például Kanadában vagy az USA-ban a 90-es években (Brei - Gambacorta 2014), de ilyen átfogó, globális követelményrendszer bevezetésére eddig nem került sor. Ez azért is meglepő, mert a bankok normál vállalkozásokhoz képest szigorúbb szabályozásának egyik fő indoka, hogy a bankok más vállalkozástí-

\footnotetext{
* A jelen kiadványban megjelenő írások a szerzők nézeteit tartalmazzák, ami nem feltétlenül egyezik a Magyar Nemzeti Bank hivatalos álláspontjával. 
pusokhoz viszonyítva a tevékenységüket lényegesen magasabb arányban végzik idegen forrás - elsősorban betét formájában történő - bevonásával, vagyis a tevékenység jellegéből adódik, hogy magas tőkeáttétel mellett múködnek, ami egyben magasabb kockázatot is jelent. A tőkeáttétel mértékének a korlátozása azonban az alkalmazható kockázati súlyok miatt eddig csak részlegesen valósulhatott meg, a szavatoló tőke és a kockázattal súlyozott mérlegfőösszeg arányában meghatározott tőkemegfelelési mutató minimumkövetelményein keresztül.

A tőkemegfelelési mutató szabályrendszere ugyan egyre szofisztikáltabb és kockázatérzékenyebb módszerekkel méri azt, hogy a bankok elégséges szavatoló tőkével rendelkeznek-e a kockázataik fedezésére, a globális pénzügyi válság tapasztalatai mégis azt mutatták, hogy egyes bankok a tőkemegfelelési mutató betartása mellett is magas tőkeáttételt tudtak kiépíteni. Míg a 90-es évek végén a legnagyobb 20 EU-s bank tőkeáttételi rátájának átlagos értéke még 6 százalék körül volt, 2008-ra ez az érték 3 százalékra, vagyis körülbelül a felére esett vissza, ami a gyakorlatban azt jelentette, hogy a mérlegfőösszeg a saját tőke 32-szeresét tette ki. Ebben az időszakban ugyanezen bankok alapvető tőkemegfelelési mutatója viszont stabilan 8 százalék körül maradt, vagyis ezt a tőkeáttétel növekedést úgy tudták elérni, hogy az nem volt hatással a kockázattal súlyozott tőkemegfelelésük mértékére (ESRB 2014). A tőkeáttétel ilyen növekedését részben a belső modellek alkalmazása által elérhető tőkekövetelmény-csökkenés, részben a gyengébb minőségű, kiegészítő alapvető tőkeinstrumentumok kibocsátása segítette. A globális pénzügyi válság során viszont éppen az ilyen, magas tőkeáttétellel működő bankoknak kellett pénzügyi nehézségekkel szembenézniük. A túlzott tőkeáttétel mint a válság egyik jelentős tényezője szerepelt a Bázeli Bankfelügyeleti Bizottság G20 csoportnak küldött jelentésében (BCBS 2010), valamint a kifejezetten az EU szabályrendszere módosításának szükségességét vizsgáló De Larosière jelentésben is (De Larosière 2009). Utóbbi külön kiemelte, hogy egyes pénzügyi intézmények esetében a tőkeáttétel akár hatvanszoros is lehetett, ami ezeket az intézményeket különösen érzékennyé tette az eszközökben bekövetkezett értékváltozásokra. Ha két bank ugyanakkora összegű szavatoló tőkével rendelkezik, akkor a bankok eszközeiben bekövetkezett értékváltozásnak (pl. értékvesztés-leírások vagy értékpapírok piaci értékének csökkenése miatt) jelentősebb lesz a negatív hatása arra a bankra, amelyik magasabb tőkeáttétel mellett működik. A Bázeli Bizottság ezért hosszas előzetes egyeztetéseket követően 2014-ben egy olyan tőkeáttételi mutató bevezetését javasolta, amelynek számítása során az eszközök és a mérlegen kívüli tételek esetében csak nagyon kevés esetben alkalmazható kockázati súly. A tőkeáttételi ráta így ugyan kevésbé kockázatérzékeny, mint a tőkemegfelelési mutató, de kiegészítő, végső limitként alkalmazva megakadályozhatja, hogy egy bank túl magas tőkeáttétel mellett múködhessen. 
A Bázeli Bizottság javaslatát eleinte sok kritika érte, mivel a tőkeáttételiráta-szabályozás a tőkemegfelelési mutatóhoz képest sokkal primitívebb számítási módszertant alkalmaz, és figyelmen kívül hagyja azokat a kockázatkezelési fejlesztéseket, amelyeket a bankok az elmúlt évtizedekben végrehajtottak. Jeremy Newell (2016), az USA-beli elszámolóházak érdekvédelmi szervezetének vezető jogásza hasonlata szerint olyan ez, mintha egy ország valamennyi útjára ugyanazt a sebességkorlátozást vezetnék be, függetlenül attól, hogy autópályáról vagy iskolaövezetről van szó.

Más kritikák szerint a tőkeáttételi ráta bevezetése nem fogja a bankok szavatoló tőkéjének a növekedését eredményezni, ráadásul fennáll a veszélye annak, hogy az alacsony kockázati súlyú ügyletek (különösen a lakossági jelzáloghitelek) jóval drágábbak lesznek, illetve értékpapírosítással vagy más szereplők bevonásával a bankrendszeren kívülről kerülnek majd finanszírozásra, márpedig egy ilyen folyamat eredményeként a bankrendszerben maradt követelések átlagos kockázati szintje magasabb lesz (Marquardt - Blåvarg 2010), ami gyengíteni fogja a pénzügyi stabilitást.

A tőkeáttételi ráta önálló eszközként való alkalmazása esetén ezeket a bírálatokat jogosnak is tekinthetnénk, a tőkeáttételiráta-szabályozás bevezetésével azonban a Bázeli Bizottság nem helyettesíteni akarja a tőkemegfelelési követelményeket, hanem kiegészíteni (backstop measure). Az EKB munkatársai az EU-bankok adatainak elemzésével megvizsgálták, hogy a tőkeáttételi rátát ért kritikák mennyire érvényesülnek a gyakorlatban, és arra a következtetésre jutottak, hogy maga a tőkeáttételi ráta bevezetése valóban ösztönzi a bankokat a magasabb kockázatvállalásra, de a tőkeáttételi mutató követelmény bevezetéséből származó nagyobb rendelkezésre álló tőke ezt a negatív hatást megfelelően ellensúlyozza (Smith et al. 2017).

Mivel a bankok számára az újabb tőke bevonása költségekkel jár, logikus lépés, hogy azokat magasabb hozammal rendelkező, de ugyanakkor kockázatosabb eszközökbe fektetik. Ezt azonban nem tehetik meg korlátlanul, hiszen a kockázattal súlyozott tőkemegfelelési követelmények előbb-utóbb meggátolják a további kockázatvállalást. Azon bankoknak ugyanakkor, amelyek már eleve magas tőkeáttétellel működnek, a követelmény teljesítéséhez többlettőkét kell bevonniuk. Összességében így a tőkeáttételi ráta bevezetése a biztonságosabb bankrendszer kialakulásának irányába hat.

Smith egy másik munkájában azzal is érvel a tőkeáttételi ráta bevezetése mellett, hogy a kockázattal súlyozott tőkemegfelelési követelményeknek mindig megmarad az a hiányossága, hogy a kockázati súlyok mértékét a múltbeli tapasztalatok alapján határozza meg. Ezek a jövőre nézve tévesek lehetnek (Smith 2020). A modellek alapján számított, de akár még a sztenderd módszerben használt kockázati súlyokról is kiderülhet, hogy a múltbeli események alapján alábecsülték a tényleges kockáza- 
tokat, ezeket a tévedéseket viszont a tőkeáttételi ráta megfelelően ellensúlyozhatja. A kockázati súlyozás ezen hibáinak ellensúlyozására eddig a legfontosabb eszköz a 2. pillérben előírható felügyeleti többlettőke-követelmény volt, de a jövőben ezt szolgálja majd az output floor bevezetése is (részletesen ld. 5.3.3. pont).

Az EU a CRR ${ }^{1}$ módosításával vette át a bázeli tőkeáttételi ráta ajánlást, ennek megfelelően az EU-ban a ráta minimum követelményének való megfelelés 2021. június 28-tól lesz kötelező. A tőkeáttételi ráta minimumszintjének meghatározása így a tagállamokban közvetlenül hatályos EU-rendeletben történik meg, vagyis magát a követelményt Magyarországon jogszabályokban külön nem határozzák meg. A hitelintézeti törvény (Hpt.)² 2020 decemberétől azonban számos, a tőkeáttételi rátához kapcsolódó szabályrendszerrel egészült ki, így különösen a túlzott tőkeáttétel kockázata miatt előírható felügyeleti többlettőke-követelmény és tőkeajánlás meghatározásának szabályaival, valamint a tőkeáttételi mutató pufferkövetelmény nemteljesítése esetén alkalmazandó intézkedésekkel.

\section{A tőkeáttételi ráta számítása és a hozzá kapcsolódó minimumköve- telmény}

A tőkemegfelelési mutatóhoz hasonlóan a tőkeáttételi ráta kiszámításának a módját is a CRR határozza meg. A kétfajta tőkekövetelmény-előírás sok esetben hasonlít egymásra, hasonló fogalmakat és számítási eljárásokat is alkalmaznak (így például a tőkeáttételi ráta is a tőkemegfelelési mutató számítása során használt alapvető tőke (T1) értékkel számol). Ugyanakkor sok fontos eltérés is van közöttük (Id. 1. táblázat).

\footnotetext{
${ }^{1}$ A hitelintézetekre és befektetési vállalkozásokra vonatkozó prudenciális követelményekről és a 648/2012/ EU rendelet módosításáról szóló 575/2013/EU (2013. június 26.) európai parlamenti és tanácsi rendelet ${ }^{2}$ A hitelintézetekről és a pénzügyi vállalkozásokról szóló 2013. évi CCXXXVII. törvény: https://net.jogtar.hu/ jogszabaly?docid=a1300237.tv
} 


\begin{tabular}{|c|c|c|}
\hline \multicolumn{3}{|c|}{$\begin{array}{l}\text { 1. táblázat } \\
\text { A tőkemegfelelési mutató és a tőkeáttételi ráta szabályrendszere közötti különbségek }\end{array}$} \\
\hline & Tőkemegfelelési mutató & Tőkeáttételi ráta \\
\hline $\begin{array}{l}\text { Használt } \\
\text { tőkekategória }\end{array}$ & $\begin{array}{l}\text { Három szintű: elsődleges alapvető tőke, } \\
\text { alapvető tőke, teljes szavatoló tőke }\end{array}$ & $\begin{array}{l}\text { Csak az alapvető tőkére vonatkozóan } \\
\text { állapít meg minimumkövetelményt }\end{array}$ \\
\hline $\begin{array}{l}\text { Kitettségek } \\
\text { mérése }\end{array}$ & $\begin{array}{l}\text { Részletes módszertan a kockázati súlyok } \\
\text { meghatározására, a kockázati súly } \\
\text { többféle számítási módszere is } \\
\text { alkalmazható (pl. sztenderd módszer, } \\
\text { belső modellek) }\end{array}$ & $\begin{array}{l}\text { Csak kevés kockázati súly alkalmazható, } \\
\text { a számítási módszertan egységes }\end{array}$ \\
\hline $\begin{array}{l}\text { Összesített } \\
\text { kitettségek }\end{array}$ & Teljes kockázati kitettségérték & Teljes kitettségérték \\
\hline $\begin{array}{l}\text { Figyelembe vett } \\
\text { kockázatok }\end{array}$ & $\begin{array}{l}\text { Hitelezési, piaci és múködési kockázatok, } \\
\text { kiegyenlítési kockázat, CVA }\end{array}$ & $\begin{array}{l}\text { Nincsenek külön kockázati kategóriák } \\
\text { meghatározva, a minimumkövetelmény } \\
\text { a kitettségek összegéhez és típusához } \\
\text { viszonyított }\end{array}$ \\
\hline $\begin{array}{l}\text { SREP } \\
\text { tőkekövetelmény }\end{array}$ & $\begin{array}{l}\text { A mikroprudenciális felügyeleti hatóság } \\
\text { a 2. pillér keretében bármilyen releváns } \\
\text { kockázatra többlettőke-követelményt } \\
\text { határozhat meg }\end{array}$ & $\begin{array}{l}\text { Többlettőke-követelmény csak a túlzott } \\
\text { tőkeáttétel kockázata miatt írható elő3 }\end{array}$ \\
\hline Tókepufferek & $\begin{array}{l}\text { Kombinált makroprudenciális tőkepuffer } \\
\text { követelmény (tőkefenntartási, } \\
\text { anticiklikus, G-SII, O-SII, } \\
\text { rendszerkockázati) }\end{array}$ & $\begin{array}{l}\text { Egyelőre csak a G-SII intézmények } \\
\text { esetében növekszik a tőkeáttételi ráta } \\
\text { minimumkövetelménye (de később ez } \\
\text { kiterjedhet O-SII intézményekre is) }\end{array}$ \\
\hline
\end{tabular}

A hitelintézeteknek már jelenleg is jelenteniük kell negyedévente a felügyeleti hatóságnak a tőkeáttételi rátájuk aktuális értékét, a CRR hatályos szövege szerint számítva. A CRR2 ${ }^{4}$ tőkeáttételi rátára vonatkozó új szabályai 2021. júniustól válnak hatályossá, és több helyen pontosítják a teljes kitettség eddig alkalmazott számításának szabályait. A változások jellemzően a számítás során figyelembe veendő kitettségek körét, a számításuk módját pontosítják, valamint új mentesítési szabályokat vezetnek be. Ezek a változások így többnyire csak enyhítik a követelményeket, mert több eszköz, illetve mérlegen kívüli tétel esetében teszik lehetővé a teljes kitettségérték csökkentését. A CRR2-ben végrehajtott módosítások többsége a Bázel III ajánláshoz való közelítést szolgálja.

A változások jellege alapján megállapítható, hogy a magyar intézmények esetében a jelenlegi, még a CRR2 előtti szabályok alapján számított és jelentett tőkeáttételi mutató értékeket az új előírások nem fogják lényegesen módosítani.

\footnotetext{
${ }^{3}$ A CRR 4.cikk (1) bekezdés 94. pontja által meghatározott definíció szerint a túlzott tőkeáttétel kockázata: „egy intézmény tőkeáttétel vagy feltételes tőkeáttétel miatti sérülékenységéből eredő kockázat, amely üzleti tervében nem tervezett korrekciós intézkedéseket tehet szükségessé, beleértve eszközök kényszereladását, ami veszteségeket vagy fennmaradó eszközeinek értékelési kiigazítását eredményezheti".

${ }^{4}$ Az 575/2013/EU rendelet módosításáról szóló 2019/876 (2019. május 20.) európai parlamenti és tanácsi rendelet.
} 
A bázeli ajánlás és a CRR2 a tőkeáttételi ráta minimumszintjét az alapvető tőke 3 százalékában határozta meg. Annak érdekében, hogy a tőkeáttételi ráta és a tőkemegfelelési mutató összehasonlítható legyen, ezt a minimumszintet a tőkemegfelelési mutatóhoz hasonló módon határozták meg, vagyis az alapvető tőke és a teljes kitettségérték hányadosaként. Ez a gyakorlatban még vezethet értelmezési nehézségekhez, mert a hagyományos megközelítések a tőkeáttételi mutatót általában az idegen forrás/saját forrás hányadosként értelmezték. E megközelítésben minél magasabb az érték, annál magasabb a tőkeáttétel, vagyis annál kockázatosabb az intézmény működése. $A$ bázeli és a CRR szerinti számítási módszer sajátosságai miatt azonban ez megfordul, így a tőkemegfelelési mutatóhoz hasonlóan minél magasabb a tőkeáttételi ráta értéke, annál tőkeerősebb az intézmény, vagyis annál kisebb a tőkeáttétel mértéke.

A tőkeáttételi ráta nevezőjeként meghatározott teljes kitettség értéke lényegesen eltér a tőkemegfelelési mutató számítása során használt teljes kockázati kitettségértéktől. A teljes kitettség értékének számítása során minden eszközt és mérlegen kívüli tételt 100 százalékos értékkel kell figyelembe venni, kivéve a 2. táblázatban foglaltakat.

\section{2. táblázat}

\section{Teljes kitettségben való figyelembevétel módja}

\section{Eszközök}

- Figyelmen kívül lehet hagyni azokat az eszközöket, amelyeket az alapvető tőke számítása során levontak (pl. immateriális javak, befektetések).

- Az eszközöket az értékvesztéssel és a prudens értékeléssel csökkentett értéken kell figyelembe venni.

- Az eszközök értékének megállapítása során hitelkockázat-csökkentő tételek (biztosítékok, garanciák) nem vehetők figyelembe, kivéve bizonyos előfinanszírozási vagy áthidaló hiteleket (pl. lakástakarékmegtakarítási fedezetre adott kölcsön).

- Anyavállalattal, leányvállalattal, testvérvállalattal szembeni kitettségek a felügyeleti hatóság engedélye esetén mentesíthetők.

- A CRR2 429a. cikk felsorol még további mentesíthető kitettségeket is, pl. exporthitelek garantált részei, az adott intézmény elfogadott központi szerződő féllel szembeni kereskedési kitettségei, bizalmi vagyonkezelés keretében kezelt eszközök, központi bankokkal szembeni egyes kitettségek.

\begin{tabular}{l|l}
\hline \multicolumn{2}{l}{ Mérlegen kívüli tételek } \\
\hline $\begin{array}{l}\text { CRR I. mellékletben } \\
\text { szereplö mérlegen } \\
\text { kívüli tételek }\end{array}$ & $\begin{array}{l}\text { A CRR 111. cikk (1) bekezdése alapján kell kiszámítani a kitettségértéket a tőke- } \\
\text { megfelelési mutató számításához hasonló módon, azzal az eltéréssel, hogy az } \\
\text { alacsony kockázatú, mérlegen kíüli tételekre nem nulla, hanem 10 százalékos } \\
\text { hitel-egyenértékesítési tényezőt kell alkalmazni. }\end{array}$ \\
\hline Derivatív ügyletek & $\begin{array}{l}\text { A derivatív ügyletek esetében a kitettségértéket a CRR2 alapján már az újonnan } \\
\text { bevezetett partnerkockázati sztenderd módszerrel kell kiszámítani. }\end{array}$ \\
\hline $\begin{array}{l}\text { Értékpapír- } \\
\text { finanszírozási } \\
\text { ügyletek }\end{array}$ & $\begin{array}{l}\text { Az értékpapír-finanszírozási ügyletek (repo, értékpapír-kölcsönzés) esetében } \\
\text { figyelembe kell venni a partnerkockázat miatti többletkockázatot. }\end{array}$ \\
\hline $\begin{array}{l}\text { Eladott } \\
\text { hitelderivatívák }\end{array}$ & $\begin{array}{l}\text { Az eladott hitelderivatívák esetében az ügylet partnerkockázatán túl egy addicio- } \\
\text { nális hitelkockázat is jelentkezik, ami az alapul szolgáló eszköz hitelminőségének } \\
\text { esetleges változásából adódik, és ezt a kockázatot is hozzá kell adni a teljes kitett- } \\
\text { ségértékhez. }\end{array}$ \\
\hline
\end{tabular}




\section{Tókeáttételi mutató adatok EU- és hazai szinten}

Az Európai Bankhatóság (European Banking Authority, EBA) az évente megjelenő Risk Assessment Reportban részletesen is elemezte az EU bankrendszerének 80 százalékát lefedő 162 bank adatait. Az ezen bankok tőkemegfelelési mutatóira és tőkeáttételi rátájára vonatkozó adatokat, illetve a Magyarországon múködő hitelintézetek hasonló adatait az 1. ábra mutatja be.

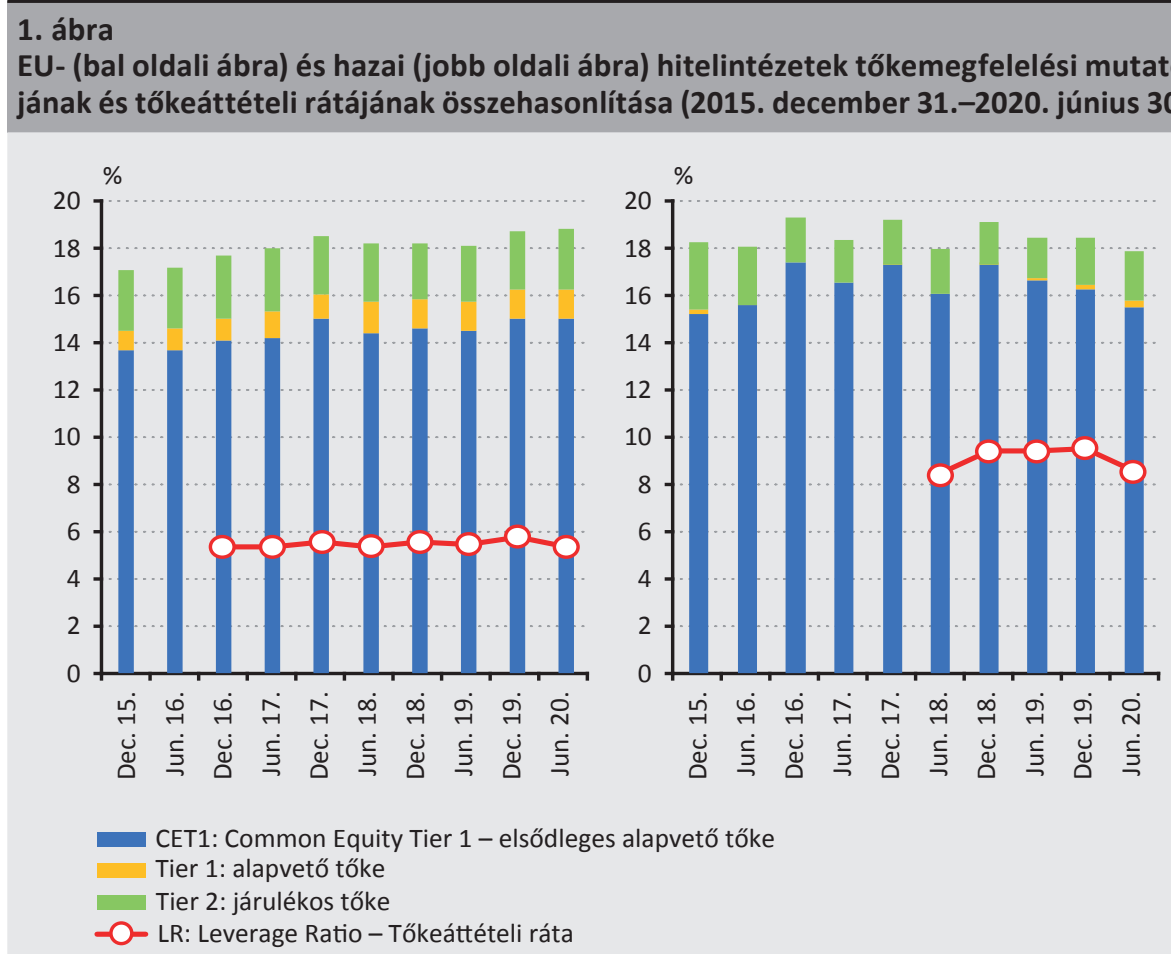

Forrás: EBA (2020a):57, MNB Hitelintézeti adatsorok

Az 1. ábrából is jól látszik, hogy a tőkemegfelelési mutató és a tőkeáttételi ráta nem mozog feltétlenül együtt. Míg EU-szinten a teljes és az elsődleges alapvető tőkemegfelelési mutatóban egyértelműen növekedés figyelhető meg, addig a tőkeáttételi ráta kis ingadozásokkal lényegében stagnál. A hazai adatok ehhez képest annyiban mutatnak eltérést, hogy Magyarországon az EU-átlaghoz képest nagyon alacsony a kiegészítő alapvető tőke aránya, ugyanakkor a tőkemegfelelési mutatóban és a tőkeáttételi rátában már megfigyelhető bizonyos együttmozgás.

Az EU-bankok tőkeáttételi ráta adatait részletesebben megvizsgálva az is látható, hogy az egyes bankok tőkeáttételi rátájában elég nagy a szórás (2. ábra). 


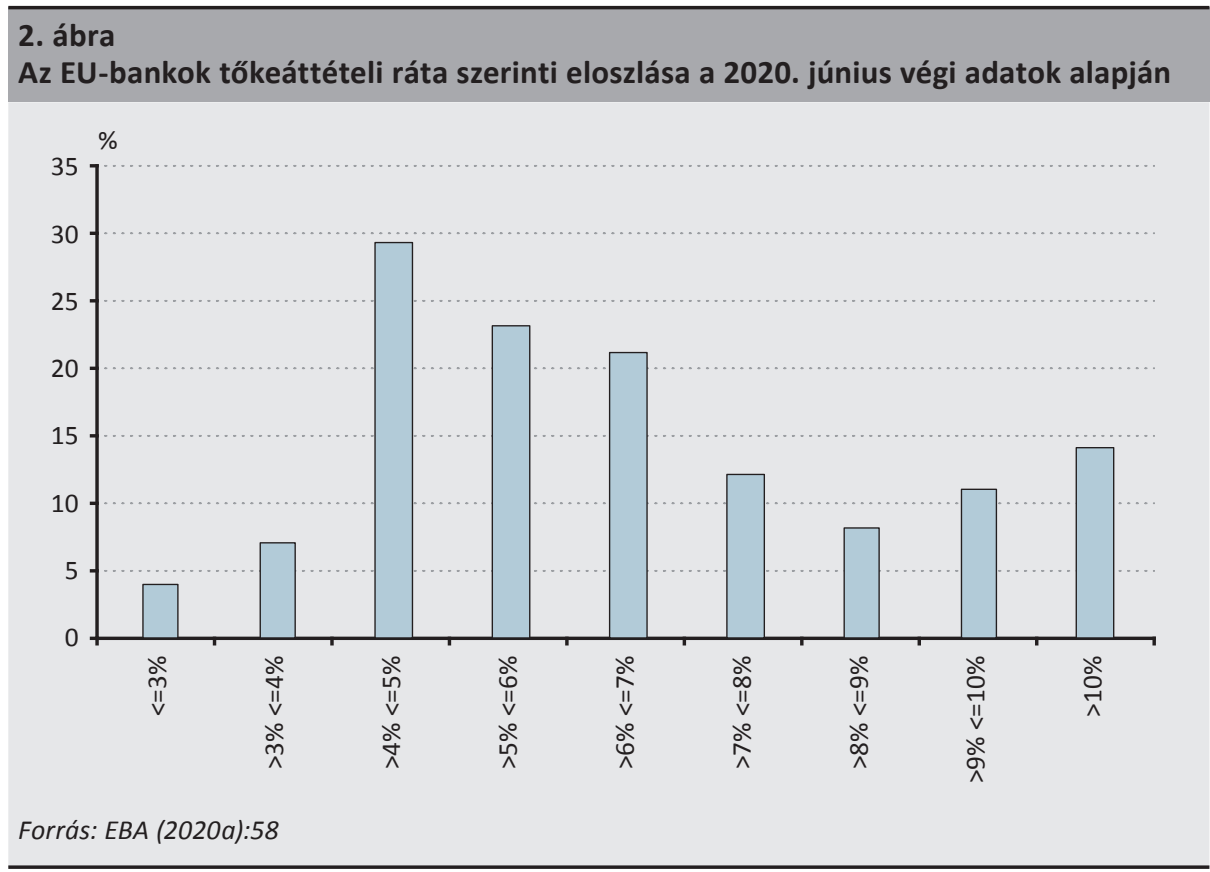

A hazai adatokat megvizsgálva összesített szinten a tőkemegfelelési mutató és a tőkeáttételi ráta értékei nagyjából együtt mozognak, ugyanakkor számos olyan egyedi banki adat található, ahol ezeknek az értékeknek az ellenkező irányú alakulása figyelhető meg. A tőkemegfelelési mutató emelkedése, viszonylagos stagnálása mellett a tőkeáttételi mutató csökkenése figyelhető meg a 2., 4. és 18. bank esetén, míg ellentétes alakulás látható a 6 . bank esetén (3. ábra).

Az összhangban nem lévő mozgásoknak számos oka lehet, a teljesség igénye nélkül vegyünk sorra pár elméleti példát (4. ábra). Amennyiben az intézmény új forrásait (pl. betéteket) alacsony kockázatú eszközökbe (pl. állampapírba) fekteti, akkor a tőkemegfelelési mutatóban az alacsony kockázati súly miatt minimális csökkenés vagy szinten maradás tapasztalható, míg a tőkeáttételi ráta jelentősen romlik a teljes kitettségérték figyelembevétele miatt. Amennyiben jelentősen megnő a járulékos tőkeelemek aránya a szavatoló tőkén belül az alapvető tőkeelemek rovására, ez szintén a tőkeáttételi ráta romlását okozza a teljes tőkét figyelembe vevő tôkemegfelelési mutató változatlansága mellett. 


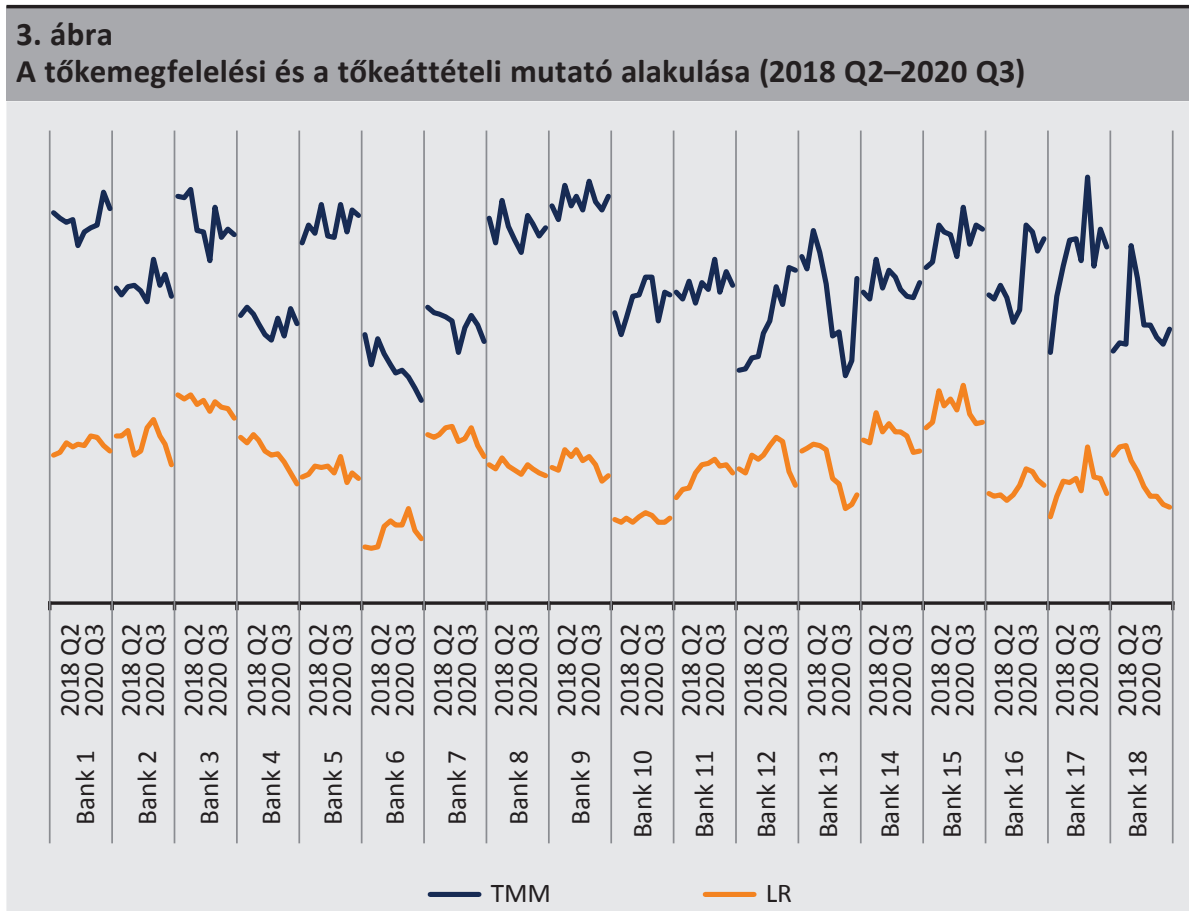

Megjegyzés: Az azonosithatóság elkerülése érdekében az outlier értékeket jelentö bankok nem szerepelnek az ábrán. A pontos értékeket adatvédelmi okokból nem közöljük, a különböző ábrákon a bankok számozása eltérő.

Forrás: MNB, felügyeleti adatszolgáltatás

4. ábra

Példák a tőkemegfelelési és a tőkeáttételi mutató együtt-nem-mozgásaira

\begin{tabular}{|c|c|c|c|}
\hline Eszközök & Források & Eszközök & Források \\
\hline $\begin{array}{l}\text { Állampapírok } \uparrow \\
\text { Egyéb eszközök }\end{array}$ & $\begin{array}{c}\text { Betétek } \uparrow \\
\text { Egyéb források }\end{array}$ & $\begin{array}{l}\text { Állampapírok } \\
\text { Egyéb eszközök }\end{array}$ & $\begin{array}{l}\text { Járulékos tőke } \uparrow \\
\text { Alapvető tőke } \downarrow\end{array}$ \\
\hline
\end{tabular}




\section{A tőkeáttételi mutató mint effektív korlát}

A tőkeáttételi ráta egyszerűsített, kockázati súlyokat figyelmen kívül hagyó megközelítése miatt ideális kiegészítője lehet a tőkemegfelelési mutató bonyolultabb, kockázatérzékeny keretrendszerének. Az intézmények kockázati profiljának függvényében a két módszertan közül jellemzően az egyik erősebb korlátot jelent, magasabb minimálisan szükséges tőkét határoz meg. A két követelményrendszer tőkeszükséglete egy elméleti határérték esetén egyenlő, ezt nevezhetjük kritikus átlagos kockázati súlynak (Kenaissi - Gimpelewicz 2017).

A kritikus átlagos kockázati súly meghatározását egy elméleti $\mathrm{ABC}$ bank példáján keresztül vezethetjük le. Tegyük fel, hogy az $A B C$ banknak nincs 2. pilléres tőkekövetelménye, és a tőkefenntartási pufferen (TFP) kívül más makroprudenciális tőkepuffer-elvárás nem vonatkozik rá. Feltételezzük továbbá, hogy a tőkeáttételi ráta (LR) és a tőkemegfelelési mutató (TMM) számításához használt kitettségérték megegyezik, vagyis nincsenek olyan kitettségei, amelyek a tőkeáttételi ráta számításában a tőkemegfelelési mutatóhoz képest többletkövetelményt, más értékelési módszertant vagy nettósítást tennének szükségessé, indokolttá. Ebben a leegyszerüsített világban a tőkeáttételi ráta módszertana alapján minimálisan szükséges tőkét a teljes kitettség 3 százaléka jelenti, míg a tőkemegfelelés szempontjából a minimális tőkét a teljes kitettség átlagos kockázati súllyal és 8,5 százalékkal ${ }^{5}$ szorzott értéke határozza meg (Kenaissi - Gimpelewicz 2017).

Tőkeáttételi tőkeszükséglet = 3\% · Teljes kitettség

Tőkemegfelelési tőkekövetelmény $=8,5 \% \cdot$ Teljes kitettség $\cdot R W^{*}$

$$
\text { Kritikus } R W^{*}=3 \% / 8,5 \%=35,3 \%
$$

A két keretrendszer közötti határt jelentő kritikus átlagos kockázati súly ekkor 35,3 százalék lesz. Amennyiben az intézmény átlagos kockázati súlya 35,3 százalék felett marad, a minimális tőkeszükségletet a tőkemegfelelés teljesítése határozza meg, melynek teljesítésével a tőkeáttételi ráta 3 százalékos minimumszintje automatikusan teljesül. A tőkeáttételi ráta csak 35,3 százalék alatt válik effektív korláttá, ekkor a nagyobb tőkeigény a 3 százalékos limit teljesítése által keletkezik (5. ábra).

\footnotetext{
${ }^{5}$ A tőkeáttételi rátával való összehasonlíthatóság érdekében csak az alapvető tőkére vonatkozó tőkemegfelelést vesszük figyelembe. A CRR alapján a tőkemegfelelés elvárt minimuma 8 százalék, T1 tőkére vonatkozóan annak 75 százaléka, azaz 6 százalék plusz 2,5 százalék tőkefenntartási puffer.
} 


\section{5. ábra \\ A tőkeáttételi ráta effektív határa}

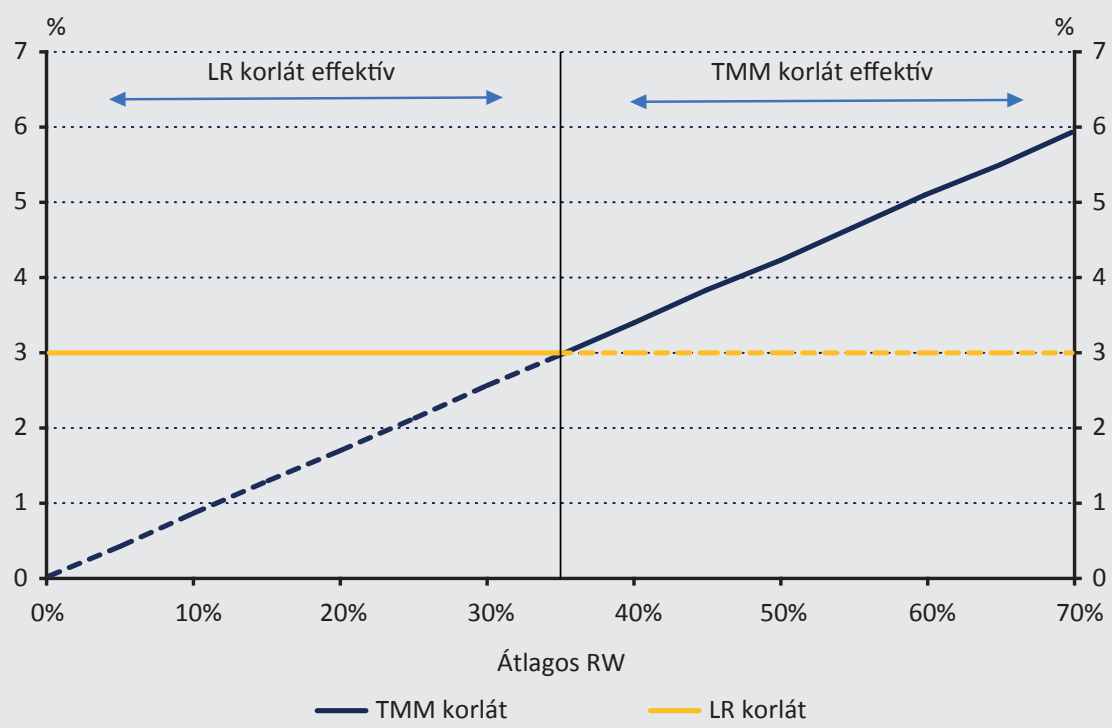

Megjegyzés: Az ábrán az alapvető tőkén kívüli forrásból megvalósuló, változatlan összetételü eszközállomány fenntartása mellett folytatódó hitelezési tevékenység lefelé történő elmozdulást jelent.

Forrás: Kenaissi - Gimpelewicz (2017) alapján szerkesztve

Amennyiben feltesszük, hogy a magyar bankszektorban a TFP-n kívüli pufferek értéke 0 és 12 százalék ${ }^{6}$ között mozog, amiből az 0-SII 0-2 százalék , a tőkeajánlás (P2G) (nyilvánosan elérhető adatok hiányában hipotetikusan) 0-10 százalék, továbbá a 2. pilléres tőkekövetelményekre is 0 és 10 százalék közötti értéket feltételezünk (nyilvános adatok itt sem elérhetőek), akkor a fentiek alapján a kritikus átlagos kockázati súly 10,7 és 35,3 százalék között lesz (6. ábra).

${ }^{6}$ CCyB $=0 \%$, SyRB $=0 \%$

https://www.mnb.hu/penzugyi-stabilitas/makroprudencialis-politika/a-makroprudencialis-eszkoztar/atulzott-hitelnovekedes-megelozeset-szolgalo-eszkozok/anticiklikus-tokepuffer,

https://www.esrb.europa.eu/national_policy/systemic/html/index.en.html

${ }^{7}$ https://www.esrb.europa.eu/pub/pdf/other/esrb.notification200827_osii_hu 617159d05f. en.pdf?62f74467cb59547c01409f286788b2aa 


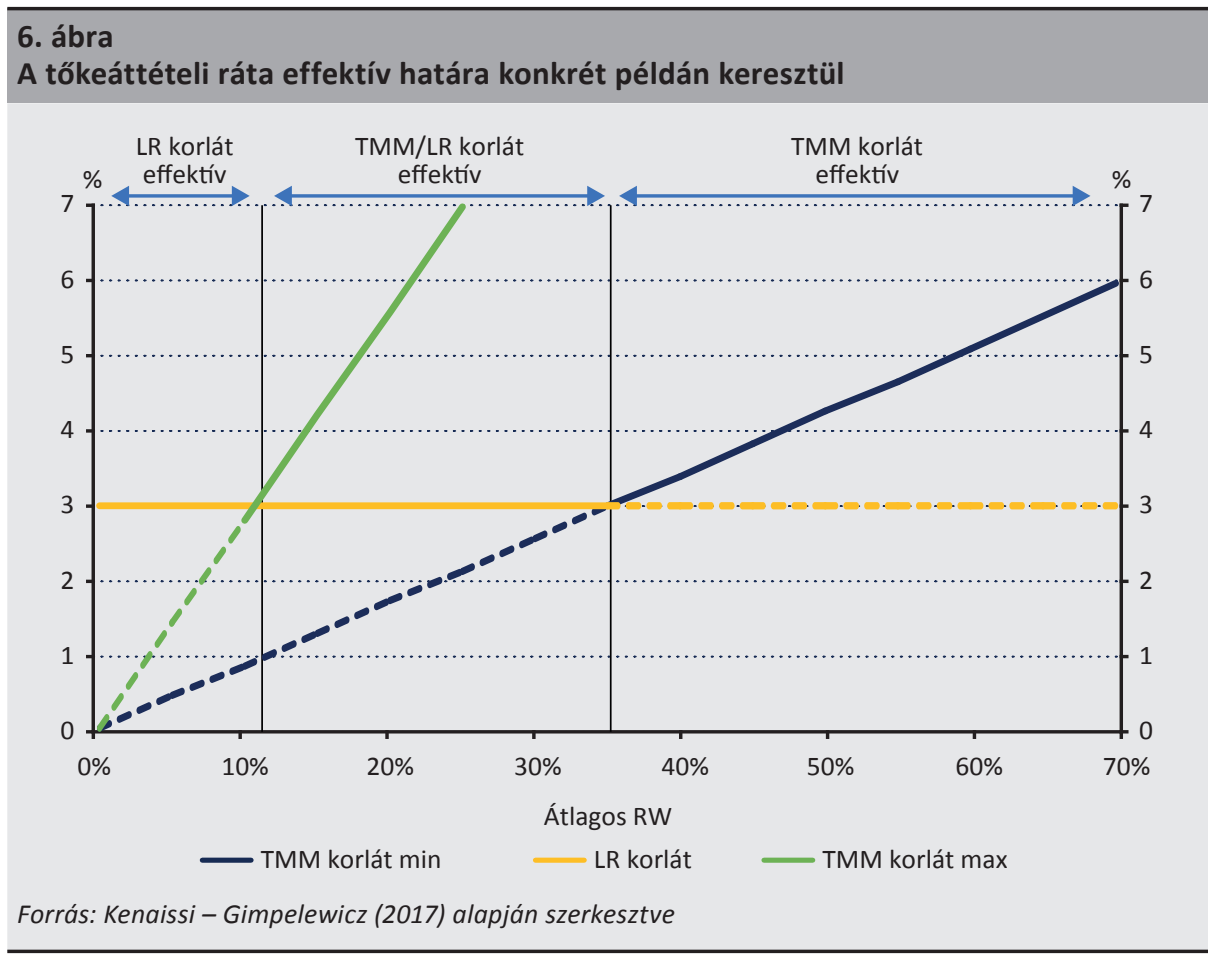

A kiszámított átlagos kockázati súly a teljes kockázattal súlyozott kitettségértékre vonatkozik, de ebből becsülhető a hitelkockázati súly is. A magyar bankszektorban a hitelkockázat aránya a teljes tőkekövetelményen belül 86 százalék ${ }^{8}$, így a tőkeáttételi ráta hozzávetőlegesen 30 százalékos átlagos hitelkockázati kockázati súly ${ }^{9}$ alatt válhat effektívvé a fenti kitettségértékek egyezőségére vonatkozó feltevésünk mellett. Magyarországon jelenleg a bankszektor ezen módszer szerint számított átlagos hitelkockázati súlya ennél magasabb, a 2018-2020 közötti időszakban minden negyedévre 43 százalék felett volt. Ugyan a csoportszintű banki adatok esetén a vizsgált időszakban előfordult több 20-30 százalék körüli érték, de ezekben az esetekben többnyire ennél alacsonyabb effektív korlátot jelentő átlagos hitelkockázati súly érvényesül az alapvető tókére vonatkozó további pufferelvárások (P2G, P2R, O-SII) miatt, így a tőkeáttételi ráta minimálisan elvárt szintje a tôkemegfelelési mutató mellett kevés esetben jelenthet valós korlátot.

\footnotetext{
${ }^{8} 2019$ végére: https://www.mnb.hu/felugyelet/idosorok/i-penz-es-hitelpiaci-szervezetek/hitelintezetek 9 Jelen esetben az átlagos hitelkockázati súly számítása: (hitelkockázati RWA)/(tőkeáttételi ráta számítása során használt kitettségérték). Megjegyzendő, hogy a nevezőben a kitettségértékek egyezőségének feltételezése miatt nem az általános értelemben vett hitelkockázati kitettség került figyelembevételre.
} 
Keresve a tőkeáttételi ráta effektívvé válásának empirikus bizonyítékát, megvizsgáltuk az alapvető tőkére vonatkozó megfelelés ${ }^{10}$, a tőkeáttételi ráta és az általunk definiált átlagos kockázati súly kapcsolatát a már korábban is használt idősoron (2018 Q2-2020 Q3). Kiszámítottuk, hogy az egyedi intézmények hányszorosan teljesítik túl az alapvető tőkére vonatkozó tőkemegfelelési elvárás abszolút minimumát (6 százalék), illetve a tőkeáttételi ráta 3 százalékos elvárását, majd a két arány különbségét vetettük össze az átlagos hitelkockázati súllyal. Amennyiben az adott intézmény esetén a tőkemegfelelési mutató túlteljesítésének aránya jelentősen nagyobb, mint a tőkeáttételi rátára vonatkozó többlet aránya, akkor várhatóan a tőkeáttételi ráta jelent hamarabb effektív korlátot, és az intézmény a függőleges tengely szerinti pozitív síknegyedben helyezkedik el. A tapasztalatok szerint ez annál valószínúbb, minél alacsonyabb az adott intézmény átlagos hitelkockázati súlya (7. ábra).

Mindez egy példán keresztül szemléltetve: ha egy intézmény alapvető tőkére vonatkozó tőkemegfelelési mutatója 9 százalék, míg tőkeáttételi mutatója csupán 3 százalék, akkor a tőkeáttételi ráta elvárás korlátozza, a 7. ábrán pedig az $y=0,5$ (mivel 9/6-3/3=0,5) vonalon helyezkedik el. A megfigyelt adatok szerint ez annál valószínúbb, minél alacsonyabb az adott intézmény átlagos hitelkockázati súlya.

\section{7. ábra \\ Az alapvető tőkére vonatkozó tőkemegfelelési és tőkeáttételi mutató kapcsolata az átlagos hitelkockázati súllyal a magyar bankszektorban 2018 Q2-2020 Q3}

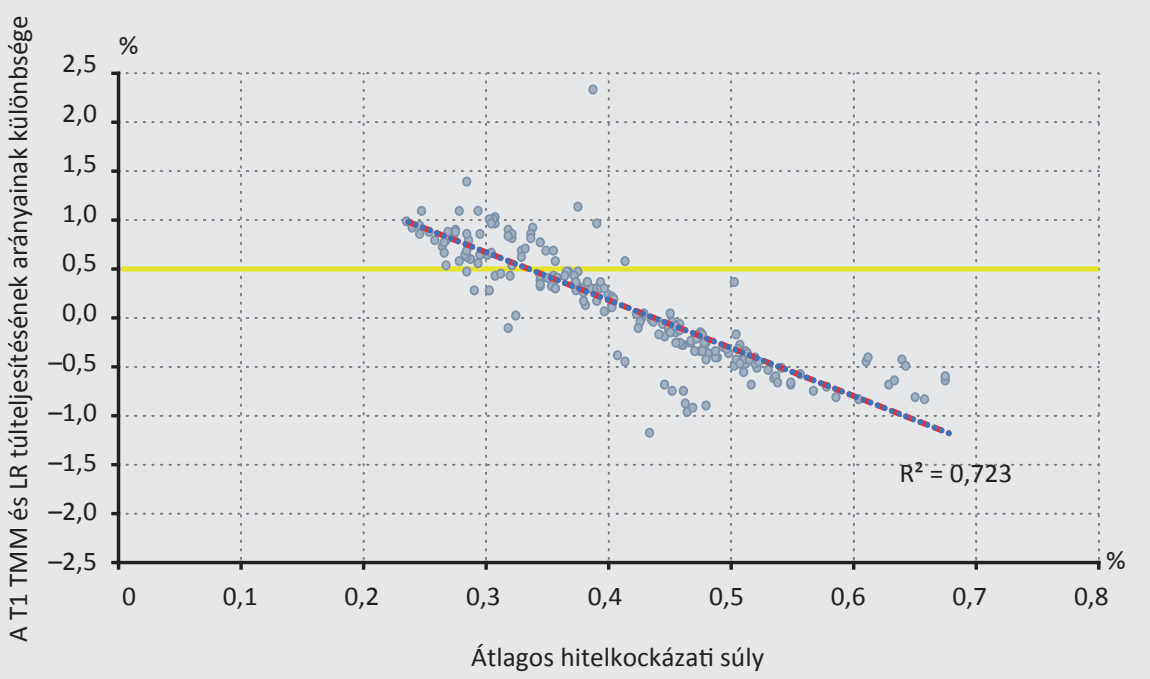

Megjegyzés: Az ábrázolás során a szerzők figyelmet forditottak az anonimitás megőrzésére. T1 TMM: alapvető tökére vonatkozó tőkemegfelelés, y értékek számítása: (T1 TMM/6\%) - (LR/3\%)

Forrás: MNB, felügyeleti adatszolgáltatás, Magyarországon bejegyzett hitelintézetek negyedéves adatai

${ }^{10} \mathrm{Az}$ alapvető tókére vonatkozó megfelelés választásának indoka a korábbiakkal összhangban az, hogy a tőkeáttételi rátában csak az alapvető tőke vehető figyelembe. 
Ha az alapvető tőkére vonatkozó elvárás helyett a teljes tőkemegfelelési mutatóval számolnánk, az összefüggést befolyásolná a járulékos tőke aránya, amely csak a teljes tőkemegfelelés esetén vehető figyelembe. Azonos paraméterekkel (szavatoló tőke, RWA, tőkeáttételi ráta kitettség, átlagos hitelkockázati súly) rendelkező bankok esetén minél nagyobb a szavatoló tőkén belül a járulékos tőke aránya, annál alacsonyabb lesz a tőkeáttételi ráta, így még valószínúbb, hogy a tőkeáttételi ráta sértése következik be hamarabb a tőkemegfelelési rátához képest. $\mathrm{A}$ 7. ábrát azonban torzítaná a járulékos tőke arányának heterogenitása a bankok között, illetve a tőkeáttételi és a teljes tőkemegfelelési mutató eltérő tőkefogalma, így az összefüggés kevésbé egyértelműen mutatkozna.

A tőkeáttételi ráta elsősorban akkor válhat effektív korláttá, ha az adott bank 1. pilléres tőkekövetelmény számítása során használt belső modellje rendkívül alacsony hitelkockázati súlyokat rendel a kitettségekhez, jelentős mennyiségú állampapírral vagy az üzleti modellje alapján elsősorban alacsony kockázatú eszközökkel rendelkezik. A fent említett 30 százalékos átlagos hitelkockázati súlytól sok esetben a jelzálogbankok, lakástakarékpénztárak és egyéb speciális üzleti modellel rendelkező egyedi intézmények maradnak el jelentősen, így esetükben a legvalószínúbb a tőkeáttételi ráta effektívvé válása. Az üzleti modell szerepét részletesen az 5.5. fejezet tárgyalja.

A fentiek alapján megállapítható, hogy a tőkeáttételi ráta minimumkövetelménye jelenleg olyan alacsony szinten van meghatározva, hogy az csak különleges esetekben okoz tényleges korlátot olyan bankok számára, amelyek a tőkemegfelelési szabályok által alacsony kockázatúnak ítélt szolgáltatásokkal foglalkoznak. A 3 százalékos minimumértéket bevezető CRR2 EU-parlamenti vitája során sok olyan módosítási javaslat is érkezett, amely az alsó határértéket lényegesen magasabban határozta volna meg (a legmagasabb javaslat a tíz százalékos minimumértékre vonatkozott).

Bár a Bázeli Bizottság a javaslatában a 3 százalékos minimumérték mellett tette le a voksát, és ezt vette át az EU is, a minimumkövetelmény optimális értékének a meghatározására vonatkozóan elég eltérő vélemények léteznek. Az ezzel foglalkozó tanulmányok abból indulnak ki, hogy meg kell találni azt az egyensúlyi értéket, amely mellett a magasabb tőkeáttételi rátából származó előnyök megegyeznek az abból származó magasabb költségekkel.

A magasabb tőkeáttételi rátából származó előnyökbe elsősorban a bankválság bekövetkezési valószínúségének a csökkenése tartozik, ennek számszerüsítése olyan tényezőktől függ, mint hogy a bankválságnak mekkora hatása van az adott ország GDP-jének a csökkenésére, vagy hogy mennyire tartós ez a hatás. A magasabb tőkeáttételi ráta költségeit pedig az jelenti, hogy ezáltal a bankoknak több tőkével kell rendelkezniük, ami miatt drágulnak a forrásköltségeik, és ez megjelenik az általuk kínált szolgáltatások árazásában is. Az ilyen tanulmányok a tőkeáttételi ráta optimális értékét a 3 százaléknál jóval magasabb szinten határozzák meg, amelyek a számítá- 
sokba bevont változók függvényében a 8-21 százalék közötti tartományokba esnek (Barth - Miller 2018).

Ezen vizsgálatok tükrében meglepőnek tűnhet a minimumkövetelmény 3 százalékban történő meghatározása, de ennek fő oka, hogy a Bázeli Bizottság a tőkeáttételi rátát csak a tőkemegfelelési mutató melletti kiegészítő eszközként kívánja alkalmazni. Ha megvizsgáljuk a tőkemegfelelési mutató szabályozását, akkor jól látható, hogy az 1988-as bevezetése óta a szabályozás számos szigorításon esett át, ideértve különösen a piaci és múködési kockázattal, a 2. pilléres tőkekövetelménnyel, a tőkepufferekkel való kiegészítést, a szavatoló tőkében figyelembe vehető instrumentumok feltételeinek szigorítását vagy a CET1 tőke szavatoló tőkén belüli részarányának növelését. Hosszabb távon ezért könnyen elképzelhető, hogy a tőkeáttételi szabályok is szigorodni fognak, amennyiben a tőkeáttételi rátáról bebizonyosodik, hogy hatékony eszköze a bankválságok megelőzésének. Ebben a kérdésben döntő lesz majd, hogy hogyan fog múködni, illetve mennyire lesz standardizálható a felügyeleti hatóságok által a túlzott tőkeáttétel kockázata miatt előírt magasabb tőkeáttételi ráta követelmény. A tőkeáttételi ráta szabályozás jövőbeni alakulását az is befolyásolhatja majd, hogy effektív korlátként való belépése esetén hogyan reagálnak a bankok. Pénzügyi stabilitási szempontból ugyanis az sem mindegy, hogy a megfelelés elérése érdekében a bankok az eszközoldalon lévő kockázataikat építik le - például értékpapírok vagy hitelek eladásával (deleverage) -, vagy pedig újabb tőkét vonnak be.

\section{A tőkeáttételi rátához kapcsolódó további fontos kérdések}

\subsection{Bázel III véglegezés, a G-SII tőkepuffer bevezetése, a központi bankokkal szem- beni kitettségek}

2017 végén a Bázeli Bizottság számos ponton módosította a Bázel III ajánlást, és ennek keretében a tőkeáttételi ráta számítási szabályai is változtak (BCBS 2017). A változások többsége nem okoz jelentős hatást, és elsősorban technikai jellegű, ide tartozik többek között a derivatívák teljes kitettségértékbe való beszámításának módja, illetve a mérlegen kívüli tételek kitettségérték-számításának összehangolása a tőkemegfelelési mutató számítása során használt kockázati súlyokkal. Történtek azonban olyan módosítások is, amelyek jelentősebb hatásokkal jártak, így különösen a G-SII ${ }^{11}$ tőkeáttételi tőkepuffer előírása és a központi bankokkal szembeni kitettségek mentesítésének a lehetősége.

A tőkeáttételi ráta puffer követelménye a G-SII rendszerszinten jelentős tőkepuffer mértékének a fele. A gyakorlatban ez azt jelenti, hogy ha például egy G-SII intézmény G-SII tőkepuffer-követelménye 1 százalék, akkor a tőkeáttételi ráta minimumszintje

\footnotetext{
${ }^{11}$ G-SII: globálisan rendszerszinten jelentős intézmény
} 
nem 3 százalék, hanem 3,5 százalék lesz. A tőkeáttételi ráta puffer nemteljesítése esetén a G-SII intézménynek a kombinált tőkepuffer követelmény nemteljesítésének esetéhez hasonlóan korlátoznia kell a kifizetéseit (osztalék, teljesítményjavadalmazás). A G-SII tőkeáttételi ráta pufferkövetelmény hatását az alábbi ábra mutatja be egy olyan G-SII intézmény vonatkozásában, amelynek a G-SII tőkepuffer-követelménye 1 százalék. Egy ilyen bank esetében a minimum CET1 tőkemegfelelési mutató követelmény az 1. pilléres minimumtőke követelményből (4,5 százalék), a tőkefenntartási tőkepuffer követelményből (2,5 százalék), valamint a G-SII tőkepuffer követelményből (1 százalék) áll, vagyis összesen 8 százalék. A tőkeáttételi ráta minimum követelménye az 1 százalék G-SII tőkepuffer-követelmény felével nő, így [3+(1×50\%) =] 3,5 százalék lesz.

\section{3. táblázat}

A CET1 tőkemegfelelési mutató és a tőkeáttételi ráta nemteljesítése esetén alkalmazandó tőkefenntartási mutatók

\begin{tabular}{c|c|c}
$\begin{array}{c}\text { CET1 tőkemegfelelési } \\
\text { mutató }\end{array}$ & Tőkeáttételi ráta & $\begin{array}{c}\text { Minimum tókefenntartási mutatók } \\
\text { (az eredmény százalékában kifejezve) }\end{array}$ \\
\hline $4,5-5,375 \%$ & $3-3,125 \%$ & $100 \%$ \\
\hline$>5,375-6,25 \%$ & $>3,125-3,25 \%$ & $80 \%$ \\
\hline$>6,25-7,125 \%$ & $>3,25-3,375 \%$ & $60 \%$ \\
\hline$>7,125-8 \%$ & $>3,375-3,50 \%$ & $40 \%$ \\
\hline$>8,0 \%$ & $>3,50 \%$ & $0 \%$ \\
\hline
\end{tabular}

Forrás: BCBS (2017)

A 3. táblázat azt mutatja meg, hogy ha a példában említett bank tőkeáttételi rátája 3,3 százalék, akkor korlátoznia kell az osztalék- vagy teljesítményjavadalmazás jellegű kifizetéseit. A kifizetés korlátozásának a részletszabályait a $C R D^{12}$, illetve ez alapján a Hpt. 96/A.§-a határozza meg. Ennek lényege, hogy a banknak az év végi nyereségének a 60 százalékát vissza kell tartania, és csak a 40 százalékát fordíthatja osztalék vagy teljesítményjavadalmazás kifizetésére. A kifizetések korlátozását egészen addig fent kell tartani, amíg a bank nem képes megfelelni ezeknek a minimumkövetelményeknek.

A bázeli ajánlással összhangban a CRR2 is bevezeti a tőkeáttételi ráta puffer követelményét, amelynek az érintett, G-SII intézményeknek 2023. január 1-től kell megfelelniük (a CRR2 eredetileg ezt a követelményt 2022. januártól vezette volna be, de a koronavírus-járvány miatt mind a Bázeli Bizottság, mind az EU egy évvel meghosszabbította a bevezetés határidejét). Magyarországon nem müködik G-SII intézmény, ugyanakkor a CRD előírásai szerint az EU-ban a Bizottság feladata lesz megvizsgálni 2022 júniusáig azt, hogy a tőkeáttételi ráta puffer követelményt ki kell-e

${ }^{12} \mathrm{~A}$ hitelintézetek tevékenységéhez való hozzáférésről és a hitelintézetek és befektetési vállalkozások prudenciális felügyeletéről szóló 2013/36/EU irányelv. 
terjeszteni az O-SII (egyéb rendszerszinten jelentős) intézményekre is. Amennyiben a Bizottság a kiterjesztést javasolja, akkor az EU Parlament és Tanács dönthet úgy, hogy a tőkeáttételi ráta puffer követelményt az O-SII intézményeknek is teljesíteni kell. Ez ma Magyarországon nyolc intézmény számára jelentene magasabb tőkeáttételi ráta követelményt.

A CRR2 tőkeáttételi ráta szabályozása szerint a nemzeti felügyeleti hatóságok különleges körülmények fennállása esetén legfeljebb egy évre megengedhetik az intézmények számára, hogy a központi bankkal szemben fennálló egyes kitettségeket ne számítsanak be a teljes kitettségértékbe. Ennek a mentesítésnek azonban az a következménye, hogy ha egy bank él a jegybanki kitettségek mentesítésével, akkor a tőkeáttételi ráta mutató követelménye is megemelkedik, tehát nem 3 százalékot, hanem annál magasabb értéket kell teljesítsen, a magasabb követelmény mértéke pedig attól függ majd, hogy mekkora a mentesített kitettség összege.

A koronavírus-járvány gazdasági hatásainak enyhítését célzó 2020. évi CRR-módosítás (quick fix) lehetővé tette, hogy ezzel a lehetőséggel a nemzeti hatóságok már a 2021. júniusi hatályba lépést megelőzően is élhessenek. Az EKB 2020 szeptemberében közzé is tette erre vonatkozó döntését ${ }^{13}$. Tekintettel arra, hogy 2021. júniusig a tőkeáttételi ráta minimum követelmény még nem hatályos, ez elsősorban abban segített, hogy az EKB által felügyelt intézmények kedvezőbb tőkeáttételi ráta adatot tudtak nyilvánosságra hozni.

\subsection{Felügyeleti többlettőke követelmény}

Új felügyeleti eszközként jelenik meg a CRDV-ben ${ }^{14}$, illetve az azt implementáló Hpt-ben 2020. decembertől, hogy az MNB a túlzott tőkeáttétel kockázata esetén többlettőke követelményt és tőkeajánlást fogalmazhat meg az intézmények számára. Ez a tőkekövetelmény és tőkeajánlás az eddig a SREP keretében előírt tőkekövetelmény mellett alkalmazható és a gyakorlatban azt jelenti, hogy az MNB a 3 százalékos tőkeáttételi rátánál magasabb minimumértéket határoz meg az intézmény számára.

A túlzott tőkeáttétel kockázata miatt előírt többlettőke követelmény azonban nem jelenhet meg a SREP keretében a 8 százalékos, kockázattal súlyozott eszközértékre meghatározott felügyeleti többlettőke követelményben, mert a túlzott tőkeáttétel kockázata miatt csak a tőkeáttételi rátára vonatkozó többlet előírása fogalmazható meg. A tőkeáttételi ráta és a tőkemegfelelési mutató esetében így hasonló szabályozási és felügyeleti eszközök múködnek (1. pilléres minimumkövetelmény, tőkepuffer, felügyeleti többlettőke követelmény, tőkeajánlás), de ez a két követelményrendszer párhuzamosan múködik, és nincs közöttük átfedés. Ez az új eszköz elsősorban

\footnotetext{
${ }^{13} \mathrm{https} / / /$ www.bankingsupervision.europa.eu/press/pr/date/2020/html/ssm.pr200917 eaa01392ca.en.html

${ }^{14}$ A 2013/36/EU irányelv módosításáról szóló 2019/878 (2019. május 20.) európai parlamenti és tanácsi irányelv
} 
azokban az országokban lehet hatékony, ahol olyan bankok múködnek, amelyek esetében a tőkeáttételi mutató effektív korlátot jelent.

\subsection{Kapcsolat más prudenciális szabályozó eszközökkel}

A bankok prudenciális szabályozásának jelenlegi eszközei hosszú fejlődési folyamat során alakultak ki. Mára elmondható, hogy ezek olyan összefüggő rendszert alkotnak, amely a bankok tevékenységének és az ahhoz kapcsolódó kockázatoknak a széles körét lefedi. Az üzleti modell, a piaci környezet, valamint a tevékenységhez kapcsolódó releváns kockázatok ugyanakkor befolyásolják azt, hogy egy adott bank számára melyik szabályozó eszköz jelenti a szúk keresztmetszetet. A Bázeli Bizottság legutóbb a 2017. év végi adatok vonatkozásában vizsgálta meg, hogy a mintában szereplő 128 bank esetében melyik prudenciális szabályozó eszköz teljesítése volt a legnehezebb (BCBS 2019). A felmérés szerint a bankok 35 százalékának az alapvető tőkemegfelelési mutató, 15 százalékának az NSFR (Net Stable Funding Ratio, nettó stabil finanszírozási mutató), 12 százalékának a TLAC (Total Loss Absorbing Capacity, teljes veszteségviselő kapacitás mutató, a CRR szabályozás szerint MREL ${ }^{15}$ ), 11 százalékának a tőkeáttételi ráta és 6 százalékának az LCR (Liquidity Coverage Ratio, likviditásfedezeti mutató) jelentette a legerősebb szabályozói korlátot. Amint ebből is látható, a tőkeáttételi ráta ugyan nem a legerősebb szabályozó eszköz, de a bankok 11 százaléka esetében mégis ez volt az, ami a legerősebb szabályozói korlátként jelent meg. A tőkeáttételi ráta szabályrendszere szoros kapcsolatban áll (a tőkemegfelelésen túl) a többi szabályozó eszközzel is, többek között az LCR-szabályokkal, a szuverén kockázatok lehetséges jövőbeli korlátozásával, az output floorral, illetve az MREL-előírásokkal is, amelyek befolyásolják a tőkeáttételi ráta szabályrendszerének hatékonyságát is.

\subsection{1. $L C R$}

A likviditásfedezeti mutató segítségével mérhető, hogy megfelelő mennyiségú és minőségú likvid eszköz áll-e a bank rendelkezésére egy esetleges rövid távú (30 napos) likviditási sokk esetén. ${ }^{16} \mathrm{~A}$ mutató nevezőjében a stressz esetén 30 napon belül várható kiáramlások súlyozott összege, számlálójában pedig a rendelkezésre álló likvid eszközök súlyozott összege szerepel. ${ }^{17}$ Az LCR-mutató változása egyes esetekben magyarázhatja a tőkemegfelelési mutató és a tőkeáttételi ráta eltérő mozgásait. Amennyiben egy bank likviditása bővítéséhez az általa gyűjtött forrásokat állampapírba vagy más alacsony kockázatú, likvid eszközbe fekteti, ez az LCR számlálójának emelkedését okozhatja, míg a tőkemegfelelésben a 0 százalékos

${ }^{15}$ MREL - Minimum Requirement for Own Funds and Eligible Liabilities - a szavatolótőkére, a leírható, illetve átalakítható kötelezettségekre vonatkozó minimumkövetelmény

${ }^{16} \mathrm{https} / / /$ www.mnb.hu/penzugyi-stabilitas/makroprudencialis-politika/a-makroprudencialis-eszkoztar/alikviditasi-es-finanszirozasi-kockazatokat-kezelo-eszkozok

${ }^{17}$ Az LCR számításához alkalmazott súlyok az EU Bizottság 2015/61 felhatalmazáson alapuló rendeletében kerültek meghatározásra, amely az 575/2013/EU európai parlamenti és tanácsi rendeletnek a hitelintézetekre vonatkozó likviditásfedezeti követelmények tekintetében történő kiegészítéséről EGTvonatkozású szöveg. 
vagy alacsony kockázati súlyú kitettség nem, vagy (alacsony pozitív súly esetén) csak kismértékben okoz változást. Ugyanezt a kitettséget viszont a tőkeáttételi ráta számításakor teljes értéken veszik figyelembe, és csökkenti annak értékét. Természetesen az LCR mozgását ebben az elméleti példában jelentősen leegyszerüsítve tekintjük, annak csak egy komponensét vesszük figyelembe. A mutató alakulásában a likvid eszközök változásán túl a nettó kiáramlások alakulása is szerepet játszik, a bank forrásszerkezetének változásán (a források eltérő kiáramlási súlyai miatt) és a beáramlások alakulásán keresztül is.

A fent említett példához hasonló irányú mozgások (az LCR emelkedése, a tőkemegfelelési mutató és a tőkeáttételi mutató szétnyílása) figyelhetőek meg a 6., 7. és 14. bank esetén jelölt időszakokban, míg az LCR csökkenése mellett a tőkemegfelelési mutató és a tőkeáttételi mutató összébb záródását látjuk a 15. és 16 . bank esetén (8. ábra).

\section{8. ábra}

\section{Az LCR, a tőkemegfelelési és a tőkeáttételi mutató alakulása 2018 Q2-2020 Q3}

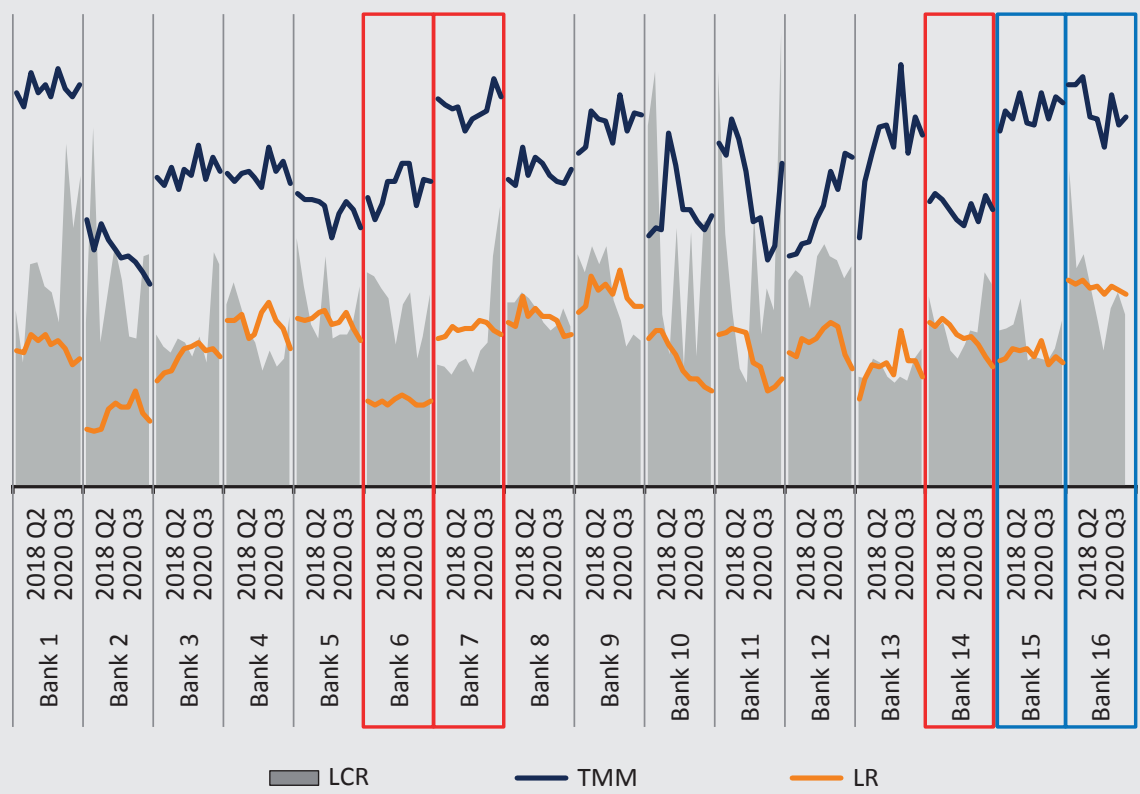

Megjegyzés: Az azonosithatóság elkerülése érdekében outlier értékeket jelentő bankok nem szerepelnek az ábrán. A pontos értékeket adatvédelmi okokból nem közöljük, a különböző ábrákon a bankok számozása eltérő.

Forrás: MNB, felügyeleti adatszolgáltatás 
Bár a tőkeáttételi ráta bevezetésének elsődleges célja a bankok megfelelő tőkehelyzetének a biztosítása, nem teljesen elhanyagolható a fizetőképesség fenntartására gyakorolt hatása sem. Mivel a tőkeáttételi ráta előírás az alapvető tőke minimumára nézve határoz meg határértéket, így megnöveli azon források arányát, amelyek egy esetleges válsághelyzetben nem vonhatók vissza, és még egy bank megrohanása esetén is biztosan és tartósan rendelkezésre állnak.

\subsubsection{Szuverén kockázatok}

Mivel a globális pénzügyi válság feltárta, hogy mennyire veszélyes lehet a kereskedelmi bankok és az államok közötti túl szoros kapcsolat, ezért a szabályozó hatóságok - így különösen a Bázeli Bizottság - már több próbálkozást tettek arra, hogy korlátozzák a bankok szuverén kitettségeit, vagyis az egyes államokkal szembeni, elsősorban állampapír vagy más finanszírozási formában megjelenő kockázatvállalásokat. A Bázeli Bizottság erről egy külön konzultációs anyagot is megjelentett (BCBS 2018). Ebben többek között felvetette a szuverén kitettségek kockázati súlyának az emelését, többlettőke-követelmény előírását a szuverénkockázati kitettségek túlzott koncentrációja esetére vagy a nagykockázat-vállalási korlát alóli mentesítés esetleges felülvizsgálatát. Végül azonban konkrét javaslat nem készült a szuverén kockázatok korlátozására, ugyanakkor megállapítható, hogy a tőkeáttételi ráta bevezetése részben alkalmas a szuverén kockázati kitettségek korlátozására is. Míg ugyanis ezek a kitettségek a tőkemegfelelési mutató számítása során 0 vagy nagyon alacsony kockázati súlyt kapnak, addig a tőkeáttételi mutatóban a teljes kitettségérték számítása során 100 százalékos súllyal szerepelnek. Ennek megfelelően az a bank, amelyik mérlegében nagy arányban szerepelnek állampapírok, nagyobb eséllyel fog beleütközni a tőkeáttételi ráta 3 százalékos korlátjába, mint a tőkemegfelelési mutató 8 százalékos minimumkövetelményébe.

\subsubsection{Output floor}

A Bázeli Bizottság 2017 decemberében tovább finomította a bankok prudenciális szabályrendszerére vonatkozó ajánlásait, és ennek keretében ismét bevezetett egy korábban már alkalmazott eszközt, az output floort. Az output floor lényege, hogy a belső modellt alkalmazó bankok esetében korlátozza a belső modell alkalmazása által elérhető tőkekövetelmény-csökkentést a sztenderd módszer szerint számított tőkekövetelmény arányában meghatározva.

Ez a gyakorlatban azt jelenti, hogy a hitelkockázati tőkekövetelmény számítására belső modellt (alap vagy fejlett IRB) alkalmazó bankoknak továbbra is ki kell számítaniuk a hitelkockázati sztenderd módszer szerint is a tőkekövetelményüket, és a végső hitelkockázati tőkekövetelményük nem lehet kevesebb, mint a sztenderd módszer szerint számított tőkekövetelmény 72,5 százaléka, még akkor sem, ha a belső modell-számítások ennél alacsonyabb tőkekövetelményt eredményeznének. Az output floor bevezetésének egyik fő oka volt, hogy a belső modellt alkalmazó bankok tőke- 
követelmény-számításai a gyakorlatban jelentős eltéréseket mutattak, és a tőkekövetelmény-különbségek nem minden esetben voltak megindokolhatóak tapasztalati tényekkel (pl. portfólió-PD-ben való eltérések, különböző üzleti modellek).

Mivel az output floor korlátozza a belső modellt alkalmazó bankok által elérhető tőkekövetelmény-csökkentést és ezáltal a portfólió egészére vetített átlagos hitelkockázati súlyt is, csökkenti a tőkeáttételi mutató tényleges korlátozó szerepét. A tőkeáttételi ráta elsősorban azoknál a bankoknál jelent tényleges korlátozást, amelyek alacsony hitelkockázati súlyok mellett múködnek, az output floor azonban a belső modellt alkalmazó bankoknál korlátozza az átlagos kockázati súly csökkenthetőségének mértékét.

Ezt az összefüggést az EBA Bázel III monitoring jelentései is feltárták és igazolták (EBA 2020b). Az EBA által végzett elemzések azt mutatták, hogy az output floor alkalmazása nélkül a vizsgálatban részt vevő bankok 71,7 százaléka esetében a kockázati súlyok alkalmazásával számított tőkemegfelelési követelmények jelentették a szigorúbb korlátot, míg a bankok 28,3 százaléka esetében a tókeáttételi ráta volt a szigorúbb szabályozó eszköz ${ }^{18}$. Az output floor bevezetése esetén ezek az arányok annyiban változnak, hogy megmarad 71,7 százalékon azon bankok aránya, amelyek esetében a tőkemegfelelési mutató a szigorúbb korlát, 12,3 százalékra csökken azon bankok aránya, amelyek esetében a tőkeáttételi ráta a korlát, és 16 százalék lesz azon bankok aránya, amelyek esetében az output floor jelenti majd a szigorúbb korlátot. Az output floor 2023-tól való fokozatos bevezetése ezért csökkenti majd azon bankok arányát, amelyek esetében a tényleges korlátot a tőkeáttételi ráta adja.

\subsubsection{MREL-követelmény elöírás}

A tôkeáttételi ráta és az MREL szoros kapcsolatát mutatja, hogy a CRR a globálisan rendszerszinten jelentős intézményekre vonatkozóan a szavatolótókére és a leírható, illetve átalakítható kötelezettségekre vonatkozó minimumkövetelményeket egyrészt a tőkemegfelelési mutató számításához használt, kockázatalapú módon számított teljes kockázati kitettségérték 18 százalékában, másrészt viszont a tőkeáttételi ráta számítása során használt, nem kockázatalapú módon számított teljes kitettségérték 6,75 százalékában határozta meg. Ennek a kettős követelményrendszernek a következtében előfordulhat, hogy lesz olyan bank, amelyik esetében a tényleges MREL-követelményt nem a teljes kockázati kitettségérték, hanem a nem kockázatalapú, teljes kitettségérték alapján számított érték jelenti majd. Az MREL-követelmény szintjét tehát az is befolyásolja, hogy egy bank mekkora tőkeáttétel mellett múködik.

Bár Magyarországon nem múködik globálisan rendszerszinten jelentős intézmény, és a hitelintézetek vonatkozásában a minimum MREL-szintet a szanálási hatóság

\footnotetext{
${ }^{18}$ Az EBA elemzése azt is megjegyzi, hogy ebben a példában a tőkeáttételi ráta szerepe túlbecsült, mert a tőkemegfelelési követelmények esetében csak az 1. pilléres előírások kerültek figyelembevételre, amik a gyakorlatban még kiegészülnek a 2. pilléres tőkekövetelménnyel és a tőkepuffer-előírásokkal.
} 
határozza meg, a teljes kitettség összegének az MREL-megfelelésre ezen hitelintézetek esetében is hatása van. A szanálási irányelv ${ }^{19}$ és azt Magyarországon implementáló szanálási törvény ${ }^{20}$ alapján ugyanis a szanálási hatóság a szavatolótőkére és a leírható, illetve átalakítható kötelezettségekre vonatkozó minimumkövetelményt nem csak a teljes kockázati kitettség, hanem a teljes kitettség arányában is meghatározza. Ennek következtében a teljes kitettség értékének az emelkedése a minimum MRELszint növekedését eredményezheti.

\subsection{A járulékos tőke szerepének további csökkenése}

A globális pénzügyi válságot követően jól megfigyelhető az a szabályozási folyamat, amely a bankok által a szavatoló tőkében figyelembe vehető járulékos tőke szerepét csökkenti. A globális pénzügyi válság egyik fontos tapasztalata volt, hogy a járulékos tőkeelemek csak korlátozottan vehetőek figyelembe a veszteségek rendezésében. Ennek oka részben az, hogy a járulékos tőke a többi szavatoló tőkével szemben rendelkezhet lejárattal, másrészt pedig ténylegesen csak a bank felszámolása esetén használható fel a veszteségek rendezésére.

A járulékos tőkeként figyelembe vehető instrumentumok ugyanis általában olyan alárendelt kölcsönök, amelyek eredeti futamideje meghaladja az öt évet, és a kölcsön nyújtója beleegyezik abba, hogy a bank felszámolása esetén a kielégítési sorrendben a részvényeseket megelőző utolsó helyre kerül. Ez a rendelkezés ugyan jelentős kockázatot jelent a hitelnyújtó számára, hiszen a többi hitelezőhöz képest az ő követelését hátrasorolják, ugyanakkor azt is jelenti, hogy a bank az ilyen instrumentumot csak egy felszámolási eljárásban használhatja fel a veszteségek rendezésére.

Ez a követelményrendszer még abban az időszakban alakult ki, amikor a banki válságkezelési eljárások elég fejletlenek voltak, és a szabályozás fő célja az volt, hogy a betétesek pénzét a bank felszámolása esetén is visszafizessék. A jelen bankszabályozás azonban már felismerte azt, hogy a bankok felszámolása hosszú, költséges folyamat, ami általában több veszteséget okoz, mint ha a bankot egy átfogó szanálási folyamat keretében megmentenék.

Az elmúlt évtized szabályozási változásai ezért abba az irányba mentek, hogy a bankok szanálhatóságát javítsák (szanálási hatóság és alap, MREL-kötelezettségek minimumkövetelményének meghatározása). Egy ilyen megközelítésben evidens, hogy a járulékos tőkeelemek szabályozásban betöltött szerepe csökkenjen, és a jobb minőségű tőkeelemeké nőjön. Ez az átalakulás több szabályozói elemben is megjelenik: ennek legegyértelmúbb eleme a tőkemegfelelési mutatón belül az elsődleges

${ }^{19}$ Az Európai Parlament és a Tanács 2014/59/EU irányelve (2014. május 15.) a hitelintézetek és befektetési vállalkozások helyreállítását és szanálását célzó keretrendszer létrehozásáról

${ }^{20}$ A pénzügyi közvetítőrendszer egyes szereplőinek biztonságát erősítő intézményrendszer továbbfejlesztéséről szóló 2014. évi XXXVII. törvény 
alapvető tőke (4,5 százalék) és az alapvető tőke ( 6 százalék) minimumkövetelmények meghatározása, aminek eredményeképpen a teljes, 8 százalékos minimum követelménynek csak a negyede fedezhető járulékos tőkével.

A járulékos tőke szerepének ezen csökkenése mutatkozik meg abban is, hogy a tőkeáttételi ráta 3 százalékos minimum követelményét - a nagykockázat-vállalási korlát vetítési alapjához hasonlóan - az alapvető tőke arányában határozták meg. A tőkeáttételi ráta és a nagykockázat-vállalás új, 2021. júniustól teljesítendő prudenciális követelményei ezért tovább csökkentik a járulékos tőke szerepét, és ezáltal ösztönzik a bankokat arra, hogy a múködésükbe olyan új tőkeinstrumentumok bevonására törekedjenek, amelyek a működés folyamatos fenntartása mellett (going concern) is alkalmasak a veszteségek leírására.

\subsection{Az üzleti modell szerepe}

A bázeli ajánlások szerinti tőkeáttételi mutató CRR-ben történő EU-implementálását megelőzően az EBA megvizsgálta a bevezetés várható hatásait, és arról részletes jelentést tett közzé (EBA 2016). A jelentésben az EBA arra is kitért, hogy melyek azok az üzleti modellek, amelyek esetében megfontolandó lehet a bankok számára sajátos szabályokat meghatározni a tőkeáttételi mutató számítására vonatkozóan. Az egyik ilyen speciális üzleti modell a jelzálogbankoké, amelyek a kereskedelmi bankokhoz képest jóval alacsonyabb átlagos kockázati súly mellett működnek, hiszen az általuk nyújtott hitelek jelzáloggal fedezve vannak, ezáltal alacsony kockázati súlyt kapnak. Az akkori mintában szereplő 12 jelzálogbank közül 2016-ban még ötnek volt a tőkeáttételi mutatója 3 százalék alatti, további ötnek pedig 5 százalék alatti.

Mivel az előzetes hatásvizsgálatok azt mutatták, hogy a tőkeáttételi ráta bevezetése a jelzálogbankok tevékenységét korlátozhatja leginkább, ezért az is felvetődött, hogy esetleg a jelzálogbankokra 3 százalék alatti tőkeáttételi ráta követelményt határozzanak meg, de végül ezt a javaslatot elvetették.

Ugyanez az EBA-jelentés feltárta azt is, hogy van egy másik üzleti modell is, amelyet az átlagoshoz képest jobban terhel a tôkeáttételi ráta követelmény. Az állami fejlesztési bankok (public development banks) szintén alacsony átlagos kockázati súly mellett múködnek, részben az ügyfélkörük, részben a tevékenységükhöz kapcsolódó állami garanciavállalási programok miatt. A CRR2 alapján az ilyen intézmények sem mentesülnek a tőkeáttételi ráta szabályozás alól, illetve alacsonyabb minimumkövetelményt sem határoztak meg számukra, ugyanakkor mégis kaptak egy lényeges kedvezményt. A teljes kitettségérték számítása során ugyanis a közszektorbeli fejlesztési hitelintézetnek ${ }^{21}$ nem kell figyelembe vennie a központi kormányzatokkal, regionális önkormányzatokkal, helyi önkormányzatokkal vagy közszektorbeli szervezetekkel szembeni, közszektorbeli beruházásokhoz és kedvezményes kölcsönök-

\footnotetext{
${ }^{21}$ Ennek az intézménytípusnak a részletes meghatározását a CRR 429a. cikk (2) bekezdése adja meg.
} 
höz kapcsolódó követeléseit. A tőkeáttételi ráta szabályozása így nem gátolhatja a közszektorbeli fejlesztéseket.

A tőkeáttételi rátáról szóló 2016-os EBA-jelentés ugyan tartalmazott egy olyan javaslatot, hogy a hitelintézeti formában múködő központi szerződő felek és központi értéktárak mentesüljenek a tőkeáttételiráta-szabályozás alól, ám a CRR-be végül csak annyi specialitás került be, hogy a központi szerződő fél által elszámolt származtatott ügyletekhez tartozó, az ilyen intézmények által az ügyfelektől kapott azon alapletéteket, amelyeket az intézmények a központi szerződő feleknek továbbítanak, nem kell beszámítani a teljes kitettségi értékbe.

\subsection{Nyilvánosságra hozatal}

Amióta a Bázel II ajánlás 2004-ben a szabályozás harmadik pilléreként bevezette a nyilvánosságra hozatali követelményeket, azóta megszokott, hogy egy új prudenciális szabály bevezetése együtt jár a nyilvánosságra hozatali szabályok bővítésével is. A CRR szerint a bankoknak már a 3 százalékos minimumérték bevezetése előtti időszakban is kellett a tőkeáttételi rátával kapcsolatban adatokat nyilvánosságra hozniuk. A CRR2 szerint a hitelintézeteknek félévente kell közzétenniük a tőkeáttételi rátájukat és a teljes kitettségértéket, illetve a nagy intézményeknek a mutató kiszámításának a részleteit is nyilvánosságra kell hozniuk.

\subsection{A tőkeáttételi ráta mint alternatív szabályozói megközelítés}

Míg a Bázeli Bizottság ajánlása és az EU szabályozása alapján a tőkeáttételi ráta backstop jellegű eszköz, addig az Egyesült Államokban a tőkeáttételi rátát alternatív szabályozói eszközként is alkalmazzák. 2020. január 1-től kezdődően az Office of the Comptroller of the Currency, a Federal Reserve és a Federal Deposit Insurance Corp. felügyelete alá tartozó, kis méretű, egyszerűbb tevékenységeket végző bankok (community banks) számára a jogszabályok lehetővé tették, hogy a bonyolult, a kockázati súlyok alapján számított tőkemegfelelési követelmények helyett csak a tőkeáttételi ráta előírásnak feleljenek meg. Azok a bankok választhatják ezt a lehetőséget, amelyek:

- konszolidált mérlegfőösszege 10 milliárd USD alatti,

- a mérlegen kívüli tételeinek mérlegfőösszeghez viszonyított aránya 25 százalék alatti,

- tőkeáttételi rátája pedig 9 százalék feletti (a pandémia miatt ezt átmenetileg 8 százalékra csökkentették, és csak 2022-től lesz 9 százalék a minimumkövetelmény).

A bankok számára azért előnyös ez az eljárás, mert így sokkal olcsóbb számukra a jogszabályi előírásoknak való megfelelés, nem kell a részletes szabályokat alkalmazva kiszámítaniuk és a felügyeleti hatóságnak jelenteniük a tőkemegfelelési mutatójukat. Abban az esetben, ha a bank tőkeáttételi rátája 9 százalék alá csökken, 
két negyedéves átmeneti időszak vár rá, amíg vagy visszaemeli a tőkeáttételi rátáját az elvárt szintre, vagy visszatér a tőkemegfelelési mutató szabályozási keretei közé.

Az Egyesült Államok ezen intézkedése nem ellentétes a Bázeli Bizottság ajánlásaival, mivel az amúgy is csak a nagyméretű, nemzetközi szinten is jelentős bankokra vonatkozik. Ez a lehetőség a bankok nagyon magas száma részére áll rendelkezésre, a 2019 második negyedévi adatok alapján az USA-ban müködő 5382 bank közül 4581 (a bankok 85 százaléka) képes lehetett arra, hogy megfeleljen az egyszerüsített megfelelés követelményrendszerének (Loudis et al. 2020). Az elmúlt évek pénzügyi folyamatai ráadásul egy olyan trendet eredményeztek, amelyben az USA-bankok tőkeáttételi rátája folyamatosan emelkedett, a magasabb, 9 százalékos tőkeáttételi ráta követelmény pedig a belépésre jogosult bankok 97 százaléka esetében öszszességében magasabb tőkekövetelményt eredményezett, mint a kockázati súlyok alapján számított tőkemegfelelési követelmények, így az áttérés nem eredményezi a pénzügyi stabilitás gyengülését sem.

Bár ez az új rendszer kedvezőnek tűnik az USA-bankok számára, a 2020. szeptemberi adatok azt mutatják, hogy a belépésre jogosult bankoknak egyelőre csak kevesebb mint egyharmada élt az egyszerűsített megfelelés lehetőségével. Ennek a fő oka az volt, hogy kevesellték az így elérhető költségmegtakarítást, a nagymértékű betétbeáramlás pedig csökkentette a tőkeáttételi rátájukat, és bizonytalanná tette a minimumkövetelménynek való tartós megfelelés képességét (Duren - Clark 2020).

Az új irány és annak tapasztalatai felhasználásával hosszabb távon akár az EU döntéshozóiban is felvetődhet egy egyszerüsített tőkekövetelmény-szabályozásra való áttérés lehetősége, hiszen az EU-ban is nagyon sok olyan kisméretű intézmény van, amelyik számára az egyszerúbb számítási módszer költségmegtakarításokat eredményezhet. A Magyarországon múködő bankcsoportok közül például csak hatnak ${ }^{22}$ magasabb a mérlegfőösszege 3000 milliárd forintnál (10 milliárd USD), vagyis egy ilyen intézkedés itthon is sok bank számára jelenthetne egyszerúbb követelményeket, de az EU számos más országában (így különösen ott, ahol kisebb méretű takarékszövetkezetek múködnek) ez a bankok számára vetítve még magasabb arányt is jelenthet.

\section{6. Összefoglalás}

A tőkeáttételi ráta bevezetése egyike a globális pénzügyi válságra adott számos szabályozói reakciónak. A Bázeli Bizottság ajánlásai alapján elkészített EU-követelményrendszer a közvetlenül hatályos EU-rendelet alapján Magyarországon is kötelezően teljesítendő minimumkövetelmény lesz 2021. júniustól. A tőkeáttételi ráta előírás jelen formájában csak kiegészíti a kockázati súlyok alapján számított

\footnotetext{
22 2020. december 31-ei adatok alapján
} 
tőkemegfelelési követelményeket, ugyanakkor hatékony eszköznek tűnik arra, hogy megakadályozza a túl magas tőkeáttétel kialakulását a bankokban, ezáltal javítja a bankrendszer ellenálló képességét, és erősíti a pénzügyi stabilitást. A tőkeáttételi ráta szoros kapcsolatban van a prudenciális szabályozás egyéb eszközeivel is, így különösen a likviditási követelményekkel, az MREL-előírásokkal és az output floorral, továbbá hatékonyan hozzájárulhat ahhoz, hogy a tőkemegfelelési mutató számítása során a kockázatok esetleges alulbecslését megfelelően korrigálja. A szabályozóknak azonban tekintettel kell lenniük arra is, hogy egy túlzottan magas tőkeáttételi ráta követelmény ugyan hatékony lehet a bankrendszer szavatolótőke-szintjének az emelésében, ugyanakkor hozzájárulhat a pénzügyi szolgáltatások drágulásához, vagy azok bankrendszeren kívülre kerüléséhez, ezért a tőkeáttételi ráta minimum szintjét csak alapos hatástanulmányok alapján lehet változtatni.

A bankok üzleti modellje jelentősen befolyásolja azt, hogy milyen hatással van rájuk az új követelmény bevezetése. A tőkeáttételi ráta várhatóan azon bankok esetében jelent majd tényleges korlátot, amelyek alacsony átlagos kockázati súly mellett jelentős járulékos tőke aránnyal múködnek. Ezen bankok elsősorban új alapvető tőke bevonásával vagy üzleti modelljük megváltoztatásával érhetik el az új követelménynek való megfelelést. A tőkeáttételi rátához kapcsolódó egyéb intézkedések, így különösen a túlzott tőkeáttétel kockázata miatti többlettőke-követelmény és tőkeajánlás felügyeleti előírásának a módszerei még kidolgozás alatt vannak, így a tőkeáttételi ráta tényleges hatásait ezen felügyeleti eljárások kialakítását és a felügyeleti folyamatokba való beépülését követően lehet majd ténylegesen megbecsülni. Könnyen

elképzelhető, hogy a gyakorlati tapasztalatok felhasználásával a későbbiekben még a tőkeáttételi ráta szabályrendszere is változni fog annak érdekében, hogy ez az új követelmény a bankok szélesebb körében múködjön effektív korlátként a túlzott kockázatvállalás visszaszorítására. A változtatások nem csak a tőkeáttételi ráta minimum szintjére vonatkozhatnak, mert már a számítási mód egyes részletszabályainak a változtatásai (pl. teljes kitettségbe való beszámítás alóli mentesítések) is olyanok lehetnek, amivel a szabályozó hatóságok befolyásolni tudják a bankok múködését.

\section{Felhasznált irodalom}

Barth, J.R. - Miller, S.M. (2018): Benefits and costs of a higher bank "leverage ratio". Journal of Financial Stability, 38(October): 37-52. https://doi.org/10.1016/j.jfs.2018.07.001

BCBS (2010): The Basel Committee's response to the financial crisis: report to the G20. Basel Committee on Banking Supervision, October. https://www.bis.org/publ/bcbs179.pdf

BCBS (2017): Basel III: High-level summary of Basel III reforms. Basel Committee on Banking Supervision, December. https://www.bis.org/bcbs/publ/d424_hlsummary.pdf 
BCBS (2018): The regulatory treatment of sovereign exposures. Discussion paper, Basel Committee on Banking Supervision, 9 March. https://www.bis.org/bcbs/publ/d425.pdf

BCBS (2019): Survey on the interaction of regulatory instruments: results and analysis, Working Paper 35, Basel Committee on Banking Supervision, March. https://www.bis. org/bcbs/publ/wp35.pdf

Brei, M. - Gambacorta, L. (2014): The leverage ratio over the cycle. BIS Working Papers No 471, Bank for International Settlements, November. https://www.bis.org/publ/work471. pdf

De Larosière, J. (2009): The High-Level Group on Financial Supervision. Report, The de Larosière Group, 25 February. https://ec.europa.eu/economy_finance/publications/pages/ publication14527_en.pdf. Letöltés ideje: 2021. február 25.

Duren, C. - Clark, R. (2020): More than 2,700 community banks say 'no thanks' to reg relief. S\&P Global Market Intelligence, 10 September. https://www.spglobal.com/ marketintelligence/en/news-insights/latest-news-headlines/more-than-2-700-communitybanks-say-no-thanks-to-reg-relief-60270427. Letöltés ideje: 2021. február 22.

EBA (2016): Report on the Leverage Ratio Requirements under article 511 of the CRR. EBA-Op-2016-13, European Banking Authority, August. https://www.eba.europa.eu/ sites/default/documents/files/documents/10180/1360107/3889de6a-42d8-4bea-8ccbca7750085fbb/EBA-Op-2016-13\%20\%28Leverage\%20ratio\%20report\%29.pdf?retry=1

EBA (2020a): Risk Assessment of the European Banking System. European Banking Authority, December. https://www.eba.europa.eu/sites/default/documents/files/document_library/ Risk\%20Analysis\%20and\%20Data/Risk\%20Assessment\%20Reports/2020/December\%20 2020/961060/Risk\%20Assessment_Report_December_2020.pdf

EBA (2020b): Basel III Monitoring Exercise - Results Based on Data as of 31 December 2019. EBA/Rep/2020/33, European Banking Authority, December. https://www.eba.europa.eu/ sites/default/documents/files/document_library/Publications/Reports/2020/960797/ Basel\%20III\%20monitoring\%20report\%20-\%20Dec\%202020.pdf

ESRB (2014): Is Europe Overbanked? Reports of the Advisory Scientific Committee, No. 4/ June 2014, European Systemic Risk Board. https://www.esrb.europa.eu/pub/pdf/asc/ Reports_ASC_4_1406.pdf

Kenaissi, M. - Gimpelewicz, M. (2017): Taking a long hard look in the mirror: should the leverage ratio reflect Pillar 2? BankUnderground, 27 April. https://bankunderground. co.uk/2017/04/27/taking-a-long-hard-look-in-the-mirror-should-the-leverage-ratio-reflectpillar-2/. Letöltés ideje: 2021. február 18. 
Loudis, B. - Nguyen, D. - Wix, C. (2020): Analyzing the Community Bank Leverage Ratio. FEDS Notes, May 26. https://www.federalreserve.gov/econres/notes/feds-notes/analyzing-thecommunity-bank-leverage-ratio-20200526.htm

Marquardt, R. - Blåvarg, M. (2010): The socio-economic consequences of introducing a leverage ratio for banks, Handelsbanken's Series of Small Publications No. 28, April. https://www.handelsbanken.com.sg/shb/inet/icentsv.nsf/vlookuppics/investor_relations_ en_socio-econ_conseq_of_lev_ratio_apr10_en/\$file/socio-ecomomic_consequences_of_ leverage_ratio_april_2010.pdf. Letöltés ideje: 2021. február 26.

Newell, J. (2016): Doing the Math on the Leverage Ratio. Bank Policy Institute, 14 July. https://bpi.com/doing-the-math-on-the-leverage-ratio/. Letöltés ideje: 2021. február 23.

Smith, J.A. - Grill, M. - Lang, J.H., (2017): The leverage ratio, risk-taking and bank stability, ECB Working Paper Series No 2079/, June 2017, European Central Bank. https://www.ecb. europa.eu/pub/pdf/scpwps/ecb.wp2079.en.pdf?97048db54786167f5a45a6426ffd80d7

Smith, J. (2020): The leverage ratio: a balance between risk and safety. BankUnderground, 6 October. https://bankunderground.co.uk/2020/10/06/the-leverage-ratio-a-balancebetween-risk-and-safety/. Letöltés ideje: 2021. február 24. 